しかし，セロハン，あるいはビニルフ イルムの場合, 一般には粘着剤をフィ

\title{
粘着テープの最近の進歩
}

上野透

最初につくられた粘着テープは，絆創亮，および電気 用ブラックテープであったが, 1925 年 R. G. Drew に よるマスキングテープの改良 ${ }^{1)}$ よって，2つの条件， 1）常温, 指圧で十分に, しかも各種の物体に接着し, 2）平滑な表面からきれいにはぎとることができること を満足して完全な形のものとなった。以来, 粘着剤とし てのゴム, フィルム材料としての繊維, プラスチックス などの高分子物質の研究の進歩，また，近代産業の合理 化への要求から著しく発展した。その進歩について，特 許，その他の文献加概要を紹介したい。

\section{1. 粘着テープの構成}

\section{1-1. Primer}

粘着テープが完全であるためには，これを使用に際し てはがすとき，また，他の物体に接着した後，きれいに はぎとられねばならぬ。このために粘着剤 (Pressure Sensitive Adhesive) と, 基材 (Backing Film) は十 分接着していなければならぬ。粘着剂はその本質からい って，圧力威受性であるために，基材の両面に対して同 ビ接着力を持つために，なんらかの処理が必要である。

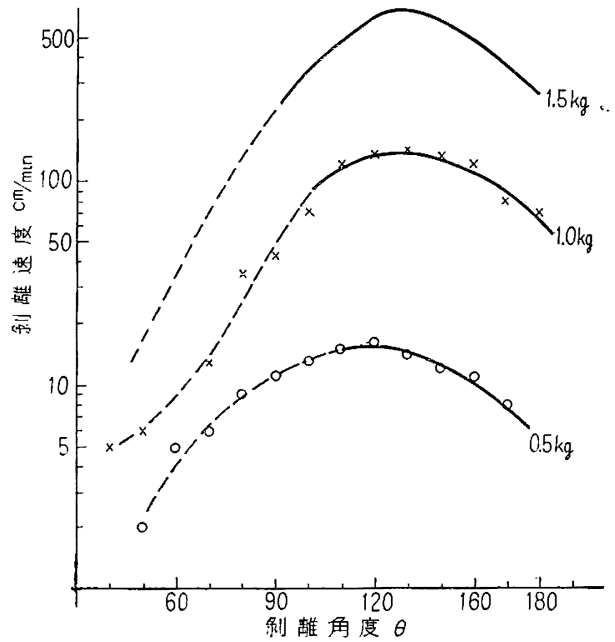

第 1 図 定荷重剝離試験 $(12 \mathrm{~m} / \mathrm{m}$ 幅の セロファンテープ使用) 破線部は 粘着剤が反対面に残るものを示す
ルム上に塗布しただけで十分である。 これは粘着剤の挙動は, いわゆる粘弾 性的なもので, 温度, 時間, 力, 特に 速度と角度によって非常に異なるから で, これらの現象については, 前田2), 小林 ${ }^{3)}$ 氏らの報告があり，また，外国 にても盛んに研究されている4”。すな わち，粘着テープを巻戾すに要する力 はその角度によって巽なり，130 付近 が最低である。このとき，反対側に粘着郕が移ろらとす れば，その関係角度は $50^{\circ}$ になり，さらに大きな力要 する。この力の差でフィルムに接着している。セロ八ン テープの場合，粘着戍が反対面に移るためには $90^{\circ}$ 以下 である。

しかし，以上の関係は普通の状態の場合であって，高 速度，あるいは低温，高温の場合には一般に成立しなく なる。このためにフィルムと粘着剤を結合するための下 塗り，すなわち Primer が必要である。

歷布，紙などの場合は一般に機械的接着でいいように考 えられるが，これのみでは不十分で，よく用いられるの は，ゴムエマルジョンによる補強を兼ねたものである また再生ゴムを使用するものもある。

セロハンの場合，初期には天然ゴムにロジンを多量に 混合したものが用いられた。しかし，これではロジンが 粘着剂層中に移行するので, これをさらに加硫し変質し ないよらにするなどが行われた。次の処法はセロハンに きわめて適当であって，かつ Primer としての基本的 考え方のものである。

\begin{tabular}{|c|c|}
\hline ポリビニルアルコー， & \\
\hline 天然ゴムラテックス & $(60 \%)$ \\
\hline ホルムアルデヒド & $(40 \%)$ \\
\hline アンモニヤ & $(28 \%)$ \\
\hline 水 & \\
\hline
\end{tabular}

親水性物質の七ロハンと PVA，また，粘着剤中の天 然ゴムとラテックス中のゴムの相互の親和性を利用した もので，しかも，極性の相違から相溶性がなく，溶液中 で混合できぬものをエマルジョンの形によって混合して いる。かつホルムアルデヒドで PVA を硬化せしめ, 耐 水性，耐溶剤性を与えている。

金属箔， $\mathrm{Al}, \mathrm{Pb}$ などが最近粘着テープとして使用さ れるが，これに対して，金属に接着性の良いマレイン酸 を含む PVC-PVAc 共重合物とニトリルゴムを混合し たものを第 1 の Primer とし，この上にニトリルゴム と GR-S の混合物を塗布し，次々と接着を良くする例 もある7。

基材として用いられるフィルム材料は一般に極性高分 
子であり, 一方, 粘着剤は 無極性の高分子であるため に, Primer としてはこの両者に接着性の良いものを混 合して使用する。あるいはその中間的な物質を使用す る。万能的な Primer として, 極性のニトリルゴムと 無極性の GR-S を混合して使用する例が多(8)。これ は, アセテート, 塩化ビニル, ナイロン, マイラーなど に十分である。これらの Primer 面に対する接着は粘 着片を乾燥した状態で接着させても溶液として叙布して も同一であって，これは粘着郕が圧力によって流動を起 し，ぬれ，吸着を生ずることによる。Primer 面への接 着力と末処理フィルム面への接着力の比で Primer の 効果が判定されるが一般に $1: 2 \sim 5$ である。

塩化ビニルなどではこれに接着性の良い高分子, 塩ビ 共重合物, 塩化ゴム, ニトリルゴムなどを粘着剤として 使用する例むあるが本質的には解決されない。

\section{1-2. 嚾型剂 (Repellent coat)}

粘着テープを巻戻すに要する力は, いわゆる粘着力で あって, これは速度とともに増加し, また低温で増加す る。このことは W. M. Bright が詳細に研究してい る ${ }^{9 !}$ c 特に高速度の場合に巻戻しを容易にするために, 粘着テープの背面を処理する。その1つは接着面積を減 少させることで, 皱付け (Creped Paper) が行われる。 セロファン, アセテートの場合は離型剤を塗布すること が適当である。たとえば次のものが使われる。

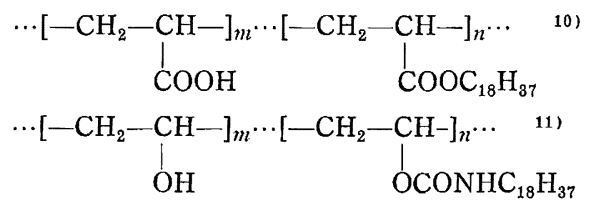

いずれも粘着剂に不活性である高級アルキル基と, フィ ルムに接着性の良い極性基をもつ高分子物質である。

油脂, 口ウなどは離型の効果はあるが被膜をつくらぬ ために粘着剤にとられ，あるいは時間とともに粘着剤中 に移行して効力を失う。このような離型剤の効果は粘着 力の比で表わされ，0.4 が適当であるとされる。

紙, 布の場合には補強も兼ねて油変性アルキッド樹脂 が用いられた ${ }^{12)}$ 。シリコーン樹脂は他のプラスチックス の成型と同様に離型剤として使用されるが，その硬化が きわめて困難であるために国内では未だ使用されていな い。

$\begin{array}{lr}\text { ポリビニルブチラール }^{13)} & 562 \\ \text { 硬化ヒマシ油 }^{(1)} & 365 \\ \text { ステアリン酸 } & 56\end{array}$

の例は両面テープ, 粘着ラベルなどの離型紙用としてす ぐれたものである。

これらの離型剂を使用した場合, 粘着テープを巻戻す とき, 高速度, 低湿で抵抗力が一定值以上で増加せず, パラパラと音をたててはがれるようになる。この現象は
粘着剤のレオロジカルな性質に関倸し, いわゆる粘着 性, Tack の現象に基くもののようである。高速度で作 業する場合には便利であるが，低温では逆に使用しがた いこともある。テープは低温で粘着性を失うと同様に高 速度, あるいは離型剤面に対して粘着性を失う。このこ とを利用して，粘着性の少ない粘着剂を使用する例があ る。また粘着剤中にステアリン酸モノグリセライドのご とき界面活性剂を加えて，選択性をもたせた例がある(14) これはセロファン, アセテートのごとき親水性, 極性表 面に対して接着力低く, ステンレススチール, ベークラ イトのごとき無極性物質に対して接着力が低下しないこ とを利用している。

\section{1-3. その他}

a) Reinforced Tape は, 一般に高分子成型品に種 々の補強が行われるように, フィルム材料の強度を増加 するものであるが，粘着テープの場合は粘着郕中に入れ られるのが普通である。アセテートフィルムを基材と し, 粘着剂中に和紙, 布, などにレーヨン, ガラス瀻維 などの長繊維を縦方向に並べたものは布以上の強度をも ち，スチールベルトに代る包装材料として使用されてい る(15) これは 1 種の Non Woven Fibre で, 結合剤と して粘着剂を利用している。その製造法は 1 例として図 に示したと抒りである ${ }^{16)}$

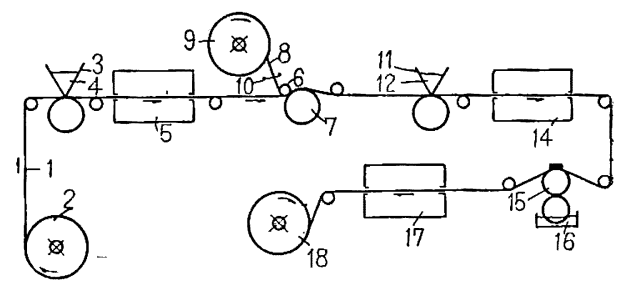

1. 紙またはフィルム，2.9. 供給ロール，3.11. 粘着剂槽, 4. 12. 粘着剂, 5.14.17. 乾燥炉, 8 . 線条, 10. 櫛, 6.7. 圧着ロール, 16. 膠その他 水溶性接着剂, 18. 巻取ロール

第 2 図補強テープ製造法の 1 例

(W. H. Paul, 日本特許 昭32-3584 による)

さらにこのものの粘着剂層の上に水溶性の樹脂を塗布 したものは補強ガムテープとして非常に抢もしろいもの である。

b) 両面テープ17) は強い和紙の両面に粘着凨を塗布 し，離型処理をした紙と巻込んだもので，金属，プラス チックスなどの接着に際して有用である。硬化型接着剂 やヒートシール接着凨, あるいは接着フィルムに代るも のとして大きく発展しつつある。

c) 粘着材料, 嵟型紙の発展によって, 粘着テープの 分野は拡大して, 広い面積のシートとして利用されるよ らになった。その 1 つは粘着ラベルで, 紙, セロファンな どに粘着剂を叙布し, 離型紙と貼り合せて適当なサイズ に打ち抜いたもので，使用に際してめくって貼るだけで 
ある。この中には離型紙を残して紙だけを打ち抜いたも のがあり，後で必要に応じて印刷できるとともに，適当 なディスペンサーを使用して，自動的に商品に貼布でき るようになっている。単にラベルのみでなく, 壁紙, 床 材料,タイルなどにこの方式を利用したものが製造され， 家庭で簡単に工作できるようになっている。

以上のごとく, 粘着テープはその性能上, また用途上 の必要性から種々構成面で進歩し, ほとんどいかなる用 途にも利用できるようになっている。

\section{2. 粘着戍の配合}

粘着剂の接着の機構については, 前記, 前田, Bright の研究があり, 最近著しく進歩しつつある。粘着剂とし て代表的なもの注次の配合である。

$\begin{array}{lc}\text { 天然ゴム } & 100^{18)} \\ \text { エステルガム } & 80 \\ \text { フレクトール H } & 2\end{array}$

この配合は今日でもセロファンなどに広く使用されて いて, 粘着性, 粘着力, 凝集力のバランスがとれていて, 特に耐寒性の点は非常にすぐれている。多くの配合はこ れから誘導されたもので，エステルガムのごときいわゆ る粘着樹脂の量によって粘着力を加減し，また，これに ラノリンのごとき㳄化剂を加えて粘着性を調節する。欠 陥は天然ゴムの老化現象で, 酸素, 日光に弱く，特に才 ゾンに弱い。上記配合のものは日光曝露で数時間内に粘 着性を失う。これはェステルガムのごとき樹脂で促進さ れるので, これに代って, 水添ロジン誘導体 ${ }^{19}$, クマ口 ン・インデン樹脂201，ポリテルペン樹脂21) が使用され る。特にポリテルペン樹脂はその重合度によって種々の 融点のものがあり，これを適当に組み合すことによって 粘着性を調節できるので有利である。ロジン誘導体もエ ステルのアルコール成分によって融点が変えられる。融 点の高い樹脂は粘着力は大きいが粘着性に乏しい。

老化を防ぐをめの老化防止剂として，一般ゴム用老防 が使用されるが，特に無変色が要求される。最近はアル キル・フェノール系のものが多く使用される。特殊な例 として, ゴムあるいは充テン材中に微量に存在する $\mathrm{Cu}$, $\mathrm{Pb}$ などの 重金属イオンによる接触作用を防ぐために, EDTA のごとき Chelating Agent を使用する例があ

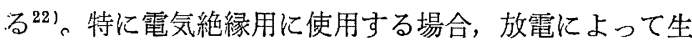
ずるオゾンで劣化することが認められるが，この点では 現在適当なものがない。一般ゴムでは Waxを配合して 々るが，これは粘着力を低下させるので好ましくない。

天然ゴムの老化に代るものとして最初に用いられたの

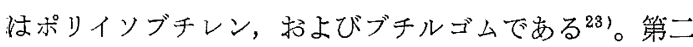
次大戦中から広く使用されているが，天然ゴムほどの耐 寒性がなく，粘着性に乏しい。また GR-S も耐久性の 点から使用されているが，特に，天然ゴムと併用するも
のは両者の利点を生かしてきわめてすぐれている。

$\begin{array}{ll}\text { Pale Crepe } & 50 \\ \text { GR-S } & 50\end{array}$

Piccolyte S-85 50

老化防止㓮 1.5

GR-S は共重合比, 重合形式によって各種のものが利 用されているが，特によく利用されるのは Styrene の $24 \%$ のものと $50 \%$ のもので非污染性のものである。ネ オプレン，ニトリルゴムは特殊な場合以外は使用されて いない。

最近，天然ゴム以上の耐寒性をもち，かつ耐久性のす ぐれたものとして，ポリビニルエーテルが使用される。 特に n-ブチル，iso-ブチルを主としたものがすぐれて いる ${ }^{25)}$ ，次の配合例がある。

$\begin{array}{lc}\text { 高分子量 n-ブチルエーテル } & \left.75^{26}\right) \\ \text { 低分子量 } \mathrm{n} \text {-ブチルェーテル } & 25 \\ \text { 老化防止剤 } & 1\end{array}$

これは未だ高価であって，特に耐久性その他優秀な性 能を必要とする場合にのみ使用されている。いかにして テープ用粘着剤としての性能が得られるか，未だはっき りした説明はなされていないが，ポリビニルエーテルあ るいは合成天然ゴムの研究によっ解明するものと思われ る。これ以外にいわゆるアクリルゴムといわれるポリア クリル酸エステル27) も使用されている。

これらのゴム系のものの他に塩化ゴム ${ }^{281}$ ，エチルセル ロース, ポリビニルブチラール29) などのプラスチック 材料も使用される。これらは可塑㓮, 油脂で軟化して弾 性を与え, 粘着樹脂を配合して粘着性にする。次の配合 はビニルテープなどに広く使用されている。
塩化ゴム
100
エステルガム
20
DBP
$100 \sim 200$

この系統のものは耐老化性はきわめてすぐれている が，粘着性乏しく，耐寒性不良であって満足なものは得 がたいが，特に電気的性質の良い点が利用されている。

特殊なタイプのものとして, 熱硬化型のものがあり,多 〈は熱硬化性のフェノール樹脂を配合してあり ${ }^{30}$ ，使用 に際して容易に巻戾しおよび接着し，その後に加熱して 十分な接着力を得るもので, 特に録音テープ, 映画フィル ムの継合せに適している。これは粘着テープがその作業 性の上から巻戻しの可能な範囲にしか接着力が上げられ ない点を改良したもので，今後この系統のものが発展す ることによって，またこれを両面テープの構成と組み 合せてアラルダイトにまさるようなものが得られるだろ 5。

シリコーン系のものは耐熱性，耐久性のすぐれたもの としてテフロン，マイラーなどと組以合せて使用されて いる。粘着テープの変形として溶剤活性型のものがあ 
り,これは Decarcomania の名称で市販されていて，ラ ベル，標示用に使用されている。

\section{3. フィルム材料}

フィルム材料はその性能に応じて種々の用途に使用さ れている。その詳細とついては J. E. Corbin ${ }^{31)}$ の報告 がある。

繊維材料の面では，アセテート，ナイロンなどが広く 使用されているが，最近はこれらと PVC，ネオプレン などの組合せによるものが多い。最近 Non Woven Fibre が発展しているが，これらも使用されるだろう。

硬質 PVCフィルムはセロファンおよびアセテートに 代るものとして研究され，すでに市販されているが，末 だ国内では良いフィルムができないので実用化していな W。

軟質 PVC は電気用, 包装用に大量に使用されてい る。この場合の最大の問題は可塑剤の移行現象で, 特に ゴム系の接着剂の場合粘着剤が㳄化しやすく，またゴム のケーブルなどの上に使用すると可塑剤がゴム中に移っ てフィルムが堅くなり，簡単に剝れるようになる。この ために最近ポリエステル系の高分子量可塑刜 ${ }^{22)}$ を使用 するよらになった。

$\begin{array}{ll}\text { Vinylite VYNS } & \left.700^{33}\right) \\ \text { Paraplex G-25 } & 200 \\ \text { DOP } & 100 \\ \text { 安定剂, 顔料 } & \text { 適量 }\end{array}$

粘着剤としては GR-S 系，ポリビニルェーテル系の ものが使用される。塩ビフィルムの可塑化の程度はテー プの作業性に関係するので，その物性についても研究が 焦んでいる。分子内可塑化 PVC を使用するのが最も望 ましいが，末だ完成されていない。

この可塑剤の移行はセロファン，アセテートの場合に も同様にやっかいな問題であって，その処理に種々のく ふらがなされている。

マイラーは強度, 電気的性質ですぐれていて,アセテー トに代って進出している。この Primer としては前記 ニトリルゴムで可能である。また $\mathrm{SiCl}_{4}$ で処理して，こ れに $\mathrm{Al}$ などを蒸着せしめ, 金属箔のような美観をもた せたものもあって，装飾用に利用されている ${ }^{34)}$ 。金属䇴 を使用することは，以前から行われたが，最近，特に印 刷配線用に利用されているようである。

ポリエチレン，テフロンは接着不可能であるとして， テープとしての使用は限られている。電子照射, 塩素処 理，金属 Naの処理などの例があるが，未だ実用化さ れないようである。簡単な方法としてポリェチレンとセ ロファンをラミネートしたものが粘着テープの基材とし て使用されている。また, テフロンの場合は,特殊な両面 テープを使用される。薄い和紙を補強材として，ポリビ
ニルェーテルを粘着郕としたものは接着力大であって， テフロンでも十分接着するといわれる。この場合は粘着 剤層が切断できないために巻戻す場合に粘着剤が反対面 に移ることがないために十分粘着テープとして利用でき $ろ^{351}$ 。

粘着テープの最近の進歩として, 以上概要を述べた。 これ以外に製造法, 試験法, あるいは理論的な研究面で いく多の進歩があるがこれれいいては前田氏の詳細な 紹介があるので省略した。

この文章は接着剂講演会 (昭和 32 年 8 月) の原稿を 補足したものであるが，ご協力を得た安武生司，岸高司 の両氏に感謝の意を表する次第である。

(積水化学工業(株) 中央研究所成型研究室)

\section{交献}

1) R. G. Drew: U. S. P. 1,760,820 (1930)

2) 前田邦夫：高分子, 5, 56, 21 27 (1956)

3）小林晴已：接着, 1, 3, 10～13（1957）

4) Adhesion and Adhesives, Fundamentals and Practice.

5) L. W. Eger 他: U. S. P. 2,726,967 (1955)

6) R. I. Coulter: U. S. P. 2,328,057 (1941); R. G. Drew : U. S. P. 2,328,066

7) M. L. Schnechtman 他: U.S. P. 2,576,148 (1951)

8) C. W. Bemmels 他: U. S. P. 2,647,843 (1953)

9) W. M. Bright: Adhesion and Adhesive, Fund. and Prac., p. 130

10) J. O. Hendricks 他: U. S. P. 2,607,711 (1952)

11) C. A. Dahlquist 他: U. S. P. 2,532,011 (1950)

12) W. Kellgren 他: U. S. P. 2,548,980 (1950)

13) W. Kellgren 他: U. S. P. 2,496,349 (1950)

14) J. A. McGarry 他： U. S. P. 2,646,371 (1953)

15) Mod. Plast., 30, 74 (May 1953)

16) W. H. Paul et al : 日本特許, 昭 32-3584

17) W. Kellgren: U. S. P. 2,206,899 (1940)

18) R. G. Drew: U. S. P. 2,156,380 (1939)

19) J. J. Berliner: Pressure Sensitive Adhesive. Material

20) H. J. Tierney: U. S. P. 2,319,959 (1941)

21) Pensilvania Industrial Chem. Corp: "Piccolyte"

22) J. F. McFlroy 他: U. S. P. 2,667,522 (1954)

23) W. Kellgren: U. S. P. 2,206,899(1940); Enjay "Vistanex" Catalogue.

24) E. O. Joesting 他: U. S. P. 2,567,671 (1951)

25) C. E. Schildknecht: Polymer Process, p. 523

26) L. W. Eger 他: U. S. P. 2,697,084 (1954)

27) C. J. Ebel : U. S. P. 2,553,816 (1951)

28) C. B. strauch: U. S. P. 2,164,359 (1938)

29) 山川, 金藤：日本特許, 昭 30-1747, 同炤 30-3693

30) C. J. Ebel: U. S. P. 2,553,816 (1951)

31) J. E. Corbin: Adhesion and Adhesive, p. 139 141

32) Z. U. Merz: Kunststoffe, 47, 3, s 102 113(1957)

33) R. J. Oace 他: U. S. P. 2,559,990 (1951)

34) 日本特許, 昭 32-5959

35) Mod. Plast. (May 1957) 